\title{
Erratum to: Reassembling Traditionality and Creativity: A Study of Place as Assemblage in Pasar Cihapit Bandung
}

Agus Surharjono Ekomadyo ${ }^{1 *}$, Tyas Santri ${ }^{2}$ and Andika Riyadi ${ }^{1}$

${ }^{1}$ Institut Teknologi Bandung, Indonesia
${ }^{2}$ Langlangbuana University Bandung, Indonesia

Original article: SHS Web of Conferences 41, 07006 (2018), https://doi.org/10.1051/shsconf/20184107006

The Author of the article should be replaced by the following text:

Agus S. Ekomadyo ${ }^{1 *}$, Tyas Santri ${ }^{2}$ and Andika Riyadi ${ }^{1}$ 